\title{
Patient as Co-Teacher on Rounds: a Pilot Study
}

\author{
Alyssa A. Perez, M.D., M.Ed. ${ }^{1,2}$, Stephen R. Pelletier, Ph.D. ${ }^{1,3}$, Isaac A. Klein, M.D., Ph.D. ${ }^{1,2}$, and \\ Helen M. Shields, M.D. ${ }^{1,2}$ \\ ${ }^{1}$ Harvard Medical School, Boston, MA, USA; ${ }^{2}$ Department of Medicine, Brigham and Women's Hospital, Boston, MA, USA; ${ }^{3}$ Office of Educational \\ Quality Improvement, Harvard Medical School, Boston, MA, USA.
}

KEY WORDS: patient as co-teacher; morning walk rounds; questions.

J Gen Intern Med 33(7):1010-2

DOI: $10.1007 / \mathrm{s} 11606-018-4421-y$

(C) Society of General Internal Medicine 2018

\section{INTRODUCTION}

Patients enjoy bedside rounds and perceive providers who engage in bedside rounds as more compassionate. ${ }^{1-4}$

The aim of this study was to determine whether the patient as co-teacher at the bedside improved the overall rating of rounds.

\section{METHODS}

This study was approved by Partners Institutional Review Board. Patients, residents, nurses, and attendings provided verbal consent for surveys and written consent to be videotaped.

Study and control patients were asked to participate (AAP and HMS). Interested study patients were "coached" for 15$30 \mathrm{~min}$ by the resident (AAP) the day before to ask a question. The resident (AAP) created a brightly colored folder (Staples File Folders, Assorted Colors \# 875429) which showed the question on the front and answer inside (see Fig. 1). The answer required approximately $30 \mathrm{~min}$ to produce. Rounds began with the patient holding up the question. The team's answers acted as the jumping off point for teaching by the resident (AAP) filmed by IAK. Control patients were filmed (HMS) during usual bedside rounds.

The bedside rounds were videotaped using an iPhone 6 and stored on a password protected Drop Box.

The videos were evaluated by physicians using a verbal and non-verbal previously validated checklist with permission. ${ }^{5}$

The first two video evaluators were trained by AAP in a short session lasting 5-10 min. When significant interobserver variability was noted, seven new evaluators were given more extensive training for at least $15-30 \mathrm{~min}^{5}$ The first set of evaluators' data was not included.

A statistician calculated descriptive statistics and analyzed data using $Z$ test for proportions.

Published online April 9, 2018

\section{RESULTS}

Forty-three patients were enrolled in the study, 36 in the control group and 7 in the pilot innovation group. One hundred twenty-one surveys were completed, 97 from the control group and 24 from the pilot group (Table 1). The overall rating for bedside rounds was significantly improved in the pilot innovation group with $91.7 \%$ of all responders (patients, attendings, residents, and nurses) giving rounds an "Excellent" rating compared to 40.2\% in the control group $(p<0.001)$. One hundred percent of patients in the innovation group rated the teaching on rounds as "Excellent" compared to $60 \%$ of patients in the control group $(p<0.001)$. Study patients' anonymous verbatim comments about what they liked best included "It was a lot of fun and interesting." and "The details about my case and pancreatitis in general." Attending comments were "How the presentation improved teampatient dynamic." and "Great format with the introduction of the clinical question by the patient followed by house staff interaction, resident education, patient narrative and concluding with a review of and rationale for guidelines applied to the specific patient." PGY-1 resident comments were "Inclusion of patient." and "Concise, high yield."

The average length of control videos (mean $9.21 \mathrm{~min}$ ) was statistically longer than that of the study videos (mean 7.04) $(p=0.045)$. Control videotapes captured the entire bedside rounds while study videos focused on the co-teaching.

Of the 24 items on the video checklists, there were eight statistically significant differences between the study group and control group. The study group outperformed the control group in terms of nodding, rapport building, and in asking open-ended questions $(p=0.013,0.008$, and 0.023 , respectively). The control group outperformed the study group in terms of plan given, plan explained, patient expresses understanding of plan, patient agrees to plan, and patient's questions answered and touch $(p=<0.001,<0.001,<0.001,<0.001$, and 0.01 , respectively).

\section{DISCUSSION}

We propose that the patient as co-teacher on bedside rounds is a useful intervention that focuses on the patient's being an important part of medical education. 

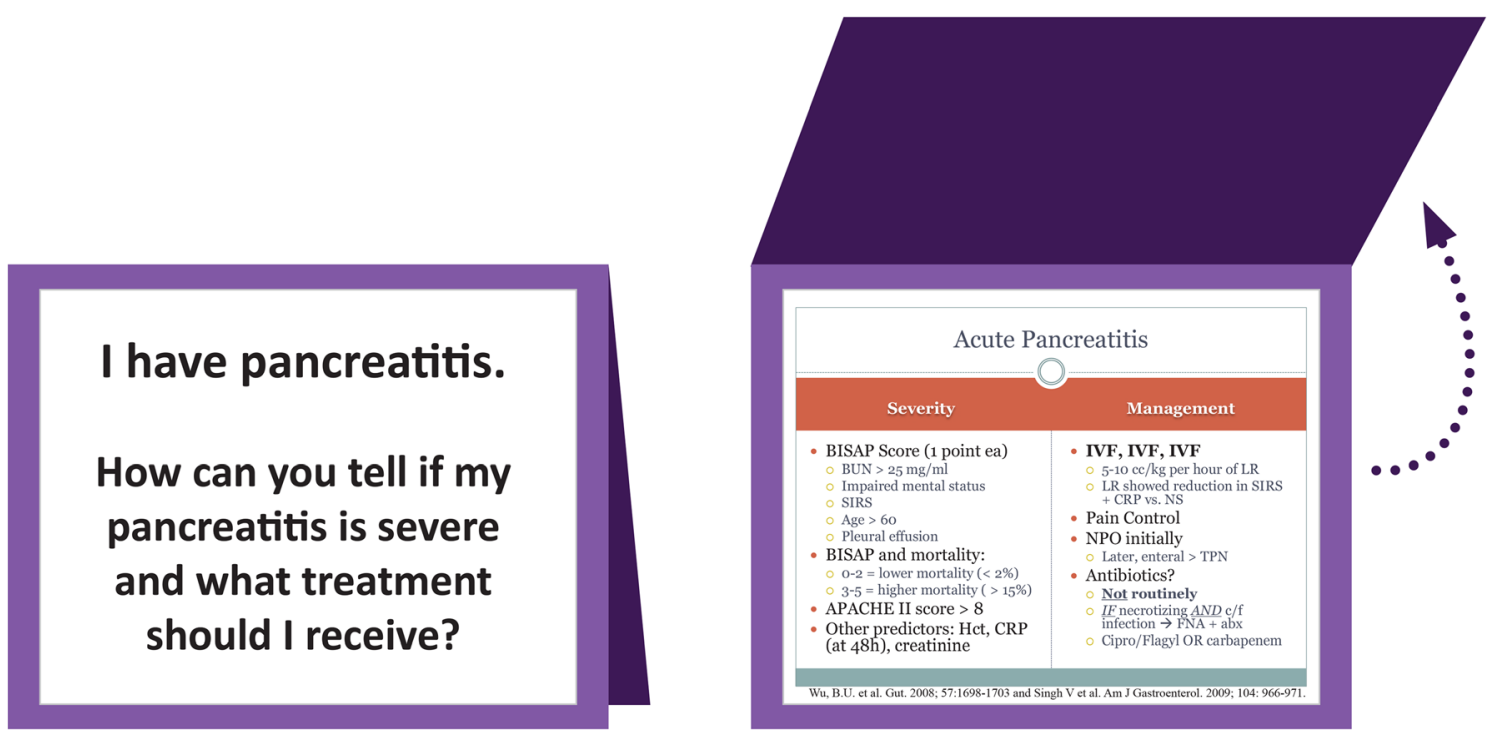

Figure 1 Example of question posed by patient on acute pancreatitis as co-teacher and evidence-based summary given by resident at bedside.

The three-pronged intervention of question followed by team responses and a visual takeaway provided a concise, high-yield educational intervention during bedside rounds.

The weaknesses of our study include the small study sample size, significantly shorter study videos, and selection of interested patients.
Strengths of the study are that it was performed on a busy inpatient medical floor and there was $75 \%$ inter-rater agreement among the coders.

The introduction of the patient as co-teacher significantly improved the overall rating of bedside rounds. Not only did patients enjoy participating in their own care, they also directly contributed to educating the team. ${ }^{6}$

Table 1 Survey of Co-Teaching by Patients and Residents on Bedside Attending Rounds

\begin{tabular}{|c|c|c|c|}
\hline & $\begin{array}{l}\text { All respondents } \\
\text { Study group } \\
(n=24)\end{array}$ & $\begin{array}{l}\text { All respondents } \\
\text { Control group } \\
(n=97)\end{array}$ & $p$ value \\
\hline \multirow{2}{*}{$\begin{array}{l}\text { Rate today's rounds } \\
\text { \% "Excellent" }\end{array}$} & 91.7 & 40.2 & $<0.001$ \\
\hline & $\begin{array}{l}\text { Attendings } \\
\text { Study group } \\
(n=7)\end{array}$ & $\begin{array}{l}\text { Attendings } \\
\text { Control group } \\
(n=23)\end{array}$ & $p$ value \\
\hline \multirow{2}{*}{$\begin{array}{l}\text { Rate today's rounds } \\
\% \text { "Excellent" }\end{array}$} & 100 & 13 & $<0.001$ \\
\hline & $\begin{array}{l}\text { Residents } \\
\text { Study group } \\
(n=5)\end{array}$ & $\begin{array}{l}\text { Residents } \\
\text { Control group } \\
(n=18)\end{array}$ & $p$ value \\
\hline \multirow[t]{2}{*}{$\begin{array}{l}\text { Rate today's rounds } \\
\% \text { "Excellent" }\end{array}$} & 80 & 11.1 & 0.004 \\
\hline & $\begin{array}{l}\text { Attendings } \\
\text { Study group } \\
(n=7)\end{array}$ & $\begin{array}{l}\text { Attendings } \\
\text { Control group } \\
(n=23)\end{array}$ & $p$ value \\
\hline \multirow[t]{2}{*}{$\begin{array}{l}\text { Bedside attending rounds contributed } \\
\text { to my daily medical education } \\
\% \text { "Strongly Agree" }\end{array}$} & 85.7 & 17.4 & 0.003 \\
\hline & $\begin{array}{l}\text { Attendings } \\
\text { Study group } \\
(n=5)\end{array}$ & $\begin{array}{l}\text { Attendings } \\
\text { Control group } \\
(n=23)\end{array}$ & $p$ value \\
\hline \multirow[t]{2}{*}{$\begin{array}{l}\text { The patient played an active role } \\
\text { in teaching during today's bedside } \\
\text { rounds } \\
\% \text { "Strongly Agree" }\end{array}$} & 85.7 & 30.4 & 0.022 \\
\hline & $\begin{array}{l}\text { Residents } \\
\text { Study group } \\
(n=5)\end{array}$ & $\begin{array}{l}\text { Residents } \\
\text { Control group } \\
(n=18)\end{array}$ & $p$ value \\
\hline $\begin{array}{l}\text { The patient played an active } \\
\text { role in teaching during today's } \\
\text { bedside rounds } \\
\% \text { "Strongly Agree" }\end{array}$ & 40 & 11.1 & 0.304 \\
\hline
\end{tabular}


Acknowledgements: Dr. Alyssa Perez was the third Nancy and Elliot Comenitz Fellow in Medical Education at Brigham and Women's Hospital. Nancy and Elliot Comenitz are grateful patients of Dr. Marshall Wolf. We are also grateful to Dr. Joel Katz for supporting this study's being done on the Integrated Teaching Unit at Brigham and Women's Hospital.

We deeply appreciate the work of all coders of the videotapes specifically Gordon Bae, MD; Rachel Blair, MD; Lawrence Borges, $M D$, MPH; Julia Caton, $M D$; Walter Kim, $M D$, $P h D$; Jennifer Nayor, $M D$; Sanjay Salgado, MD; Anubodh Varshney, MD; and Ryan Watson, MD. This study was presented as a poster at Harvard Medical School's 2016 Medical Education Day in Boston, Massachusetts.

Corresponding Author: Helen M. Shields, M.D.; Harvard Medical School, Boston, MA, USA (e-mail: hmshields@bwh.harvard.edu).

Funding Project costs were paid through the Nancy and Elliot Comenitz philanthropic fellowship Dr. Alyssa Perez was awarded.

Compliance with Ethical Standards: This study was approved by Partners Institutional Review Board. Patients, residents, nurses, and attendings provided verbal consent for surveys and written consent to be videotaped.
Conflicts of Interest: The authors declare that they do not have conflict of interest.

\section{REFERENCES}

1. Gonzalo JD, Chuang $\mathbf{C H}$, Huang G, Smith C. The return of bedside rounds: an educational intervention. J Gen Intern Med 2010; 25(8): 792798.

2. Crumlish CM, Yialamas MA, McMahon GT. Quantification of bedside teaching by an academic hospitalist group. J Hosp Med 2009; 4(5):304307.

3. Ramirez J, Singh J, Williams AA. Patient satisfaction with bedside teaching rounds compared with nonbedside rounds. South Med J. 2016; 109(2): 112-5

4. Lehmann LS, Brancati FL, Chen MC, et al. The effect of bedside case presentations on patients' perceptions of their medical care. N Engl J Med. 1997; 336 (16):1150-1155.

5. Ishikawa, H, Hashimoto $\mathbf{H}$, Kinoshita $\mathbf{M}$, et al. Evaluating medical students' non-verbal communication during the objective structured clinical examination. Med Educ 2006; 40:1180-1187.

6. Ali NB, Pelletier SR, Shields, HM. Innovative curriculum for second-year students: practicing communication skills with volunteer patients giving immediate feedback. Adv Med Educ Pract 2017; 9: 337-345. 